\title{
Pelatihan Percepatan Menghapal Ayat Suci Al-Qur'an Melalui Penerapan Metode Tiqrar Bagi Murid TPA Sabilal Muhtadin Mendalo
}

\author{
Mohamad Muspawi, Sahrizal Vahlepi \\ Universitas Jambi
}

Email: muspawi01@gmail.com

\begin{abstract}
Abstrak: Menghapal ayat-ayat suci Al-Qur'an merupakan suatu kegiatan yang bernilai ibadah, hal itu dikarenakan ayat-ayat suci Al-Qur'an merupakan firman Allah SWT, yang mana setiap orang Islam yang membacanya akan memperoleh pahala dari Allah SWT. Di sisi lain, kegiatan menghapal Al-Qur'an bukan perkara gampang, dibutuhkan motivasi yang kuat dari orang yang ingin menghapalnya, dan juga dibutuhkan metode yang tepat akan memiliki keterampilan yang baik dalam menghapalnya. Tujuan pengabdian ini adalah: 1). Untuk membangun mindset kepada para murid TPA Sabilal Muhtadin Perumahan Aston Villa Mendalo Darat bahwa menghapal ayat suci Al-Qur'an merupakan hal mudah dilakukan, asalkan didukung dengan metode yang tepat. 2). Untuk membekali pengetahuan mereka mengenai metode Tiqrar dalam menghapal ayat suci Al-Qur'an bagi para murid TPA Sabilal Muhtadin Perumahan Aston Villa Mendalo Darat. 3). Untuk meningkatkan keterampilan anak-anak TPA Sabilal Muhtadin dalam menghapal ayat suci Al-Qur'an. Metode yang digunakan dalam pelaksanaan program pelatihan wirausaha ini adalah: 1) metode ceramaha, yakni memberikan penjelasan mengenai metode Tiqrar kepada para peserta, 2). Metode pencontohan, yakni tim memberikan pencontohan kepada para peserta dalam menghapal, 3) Metode pengulangan (Metode Tiqrar), yakni melakukan pengulangan terhadap apa yang dibaca dan yang akan dihapal.
\end{abstract}

Kata Kunci: Pelatihan, Metode Tiqrar, Keterampilan Menghapal.

\section{PENDAHULUAN}

\subsection{Analisis Situasi.}

Menghapal ayat suci merupakan pekerjaan mulia, bagi orang Islam yang melakukannya akan mendapatkan pahala dari Allah SWT, Rasulullah SAW bersabda:

$$
\text { روراه البخاري يقرأ القرآن و هو حافظ له مع السفرة الكر ام البررة ومثل الذي يقر أو هو يتعاهده وهو عليه شديد فله أجران. }
$$

Artinya: "Perumpamaan orang yang membaca Qur'an sementara dia telah menghafalkannya.

Maka bersama para Malaikat yang mulia. Dan perumpamaan yang membaca dalam kondisi berusaha keras (belajar membacanya) maka dia mendapatkn dua pahala.' HR. Bukhori, 4653 dan Muslim, 798.

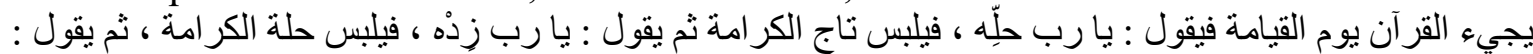

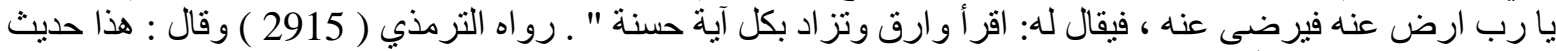

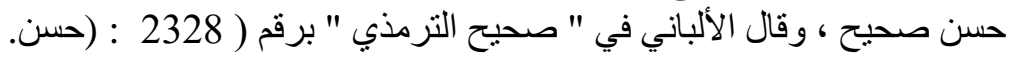

Artinya: "Qur' an datang pada hari kiamat dan mengatakan, "Wahai Tuhan, pakaikanlah. Maka dia memakai mahkota karomah (kemulyaan) kemudian mengatakan, "Wahai Tuhan, tambahkanlah dia. Maka dia memakai gelang karomah (kemulyaan). Kemudian mengatakan, "Wahai Tuhan, redoilah dia, maka (Allah) meredoinya. Dikatakan kepadanya, "Bacalah dan naiklah. Ditambah setiap ayat suatu kebaikan." HR. Tirmizi, (2915) dan mengatakan, "Hadits ini Hasan Shoheh. Albani mengatakan di Shoheh Tirmizi, no. 2328. Hasan.

Mengingat menghapal dan membaca Al-Qur'an merupakan pekerjaan yang mulia, maka membaca dan menghapalnya harus benar-benar teliti dan hati-hati supaya terjaga 
berbagai perihal yang berkaitan etika, adab, dan tata yang benar dalam membaca dan menghapal Al-Qur'an. Banyak hal yang harus diperhatikan dalam membaca dan menghapal Al-Qur'an, mulai dari sopan santun atau adab memegang, membuka, menutup, dan menyimpannya, kemudian adab berpakaian ketika membacanya, dan kesucian diri ketika hendak memegang dan membaca Al-Qur'an.

Kondisi keterampilan anak-anak TPA Sabilal Muhtadin Perumahan Aston Villa Mendalo Darat masih tergolong rendah dalam menghapal Al-Qur'an, karena dari 40 murid yang aktif belum satupun dari mereka yang sudah mampu menghapal juz 30 atau juz 'Amma. Berarti ada sesuatu kendala yang dialami oleh murid-murid TPA Sabilal Muhtadin Perumahan Aston Villa Mendalo Darat dalam menghapal Al-Qur'an. Diantara kendala tersebut ialah belum diterapkannya metode yang tepat dalam membimbing anak-anak menghapal Al-Qur'an. Oleh karena itu, tim pengabdian LPPM Universitas bermaksud memberikan pelatihan kepada para murid TPA Sabilal Muhtadin Perumahan Aston Villa Mendalo Darat, dengan harapan dapat membantu mereka lebih terampil dalam menghapal Al-Qur'an.

Tujuan dari pengabdian ini adalah: 1). Membantu para murid TPA Sabilal Muhtadin Perumahan Aston Villa Mendalo Darat dalam mengahapal AL-Qur'an. 2). Mengenalkan metode Tiqrar dan membantu mengetahui dan mempraktekkan bagaimana langkah-langkah penggunaannya. 3). Melaksanakan salah satu Tri Dharma perguruan tinggi yaitu pengabdian kepada masyarakat

\section{MATERI DAN METODE PELAKSANAAN}

Metode yang digunakan dalam pelaksanaan kegiatan pelatihan penerapan Metode Tiqrar untuk meningkatkan keterampilan menghapal ayat suci Al-Qur'an bagi anak-anak TPA Sabilal Muhtadin Perumahan Aston Villa Mendalo Darat ini adalah metode kaji tindak partisipatif karena program pelatihan ini dilakukan sebagai upaya meningkatkan keterampilan murid dalam menghapal ayat suci Al-Qur'an. Dengan menggunakan metode kaji tindak partisipatif diharapkan dapat menciptakan keyakinan bahwa murid mampu untuk menghapal ayat suci Al-Qur'an dengan baik benar serta dengan rentang waktu yang tidak lama.

Metode yang akan digunakan dalam program pengabdian mayarakat Integratif ini adalah melalui:

1) Metode ceramah, yakni memberikan penjelasan mengenai metode Tiqrar kepada para peserta,

2) Metode pencontohan, yakni tim memberikan pencontohan kepada para peserta dalam menghapal.

3) Metode pengulangan (Metode Tiqrar), yakni melakukan pengulangan terhadap apa yang dibaca dan yang akan dihapal

Sedangkan secara proses maka tim melakukan rangkaian kegiatan sebagai berikut:

1. Tahap perencanaan.

Dilakukan dengan menyusun berbagai hal yang akan disiapkan untuk pelaksanaan kegiatan pengabdian seperti rencana lokasi, materi, jadwal dan narasumber. Dengan melihat permasalahan di lapangan dan dengan menghitung berbagai pertimbangan, maka 
ditetapkan TPA Masjid Sabilal Muhtadin sebagai objek dari kegiatan ini.

2. Tahap pendekatan.

Dilakukan dengan mengunjungi lokasi pengabdian dan persiapan sarana dan prasarana sebelum pelaksanaan pengabdian dengan harapan pelaksanaan pengabdian dapat berjalan dengan lancar.

3. Tahap pelaksanaan.

Dilakukan dengan melaksanakan kegiatan pelatihan sesuai dengan prosedur yang telah disusun oleh tim pengabdian. Yakni diawali dengan mengenalkan diri kepada para peserta kegiatan pengabdian ini, kemudian mengenalkan program pengabdian ini kepada para peserta, lalu memulai latihan dalam beberapa pertemuan, dilanjutkan dengan pendalaman mengenai materi latihan, dan terakhir mengevaluasi kemampuan para peserta dalam mempraktekkan materi setelah mengikuti kegiatan pengabdian ini.

\section{HASIL DAN PEMBAHASAN}

\subsection{Hasil Pengabdian.}

Berdasarkan pengamatan selama kegiatan pengabdian kepada masyarakat berlangsung, diperoleh beberapa hasil yang positif, diantaranya adalah:

1. Para peserta menunjukkan perhatian yang tinggi terhadap materi pengabdian yang disampaikan oleh tim pengabdian. Yang mana peserta memfokuskan perhatian mereka terhadap kegiatan ini, dan peserta mengesampingkan kegiatan lainnya dalam rangka serius mengikuti kegiatan pengabdian ini.

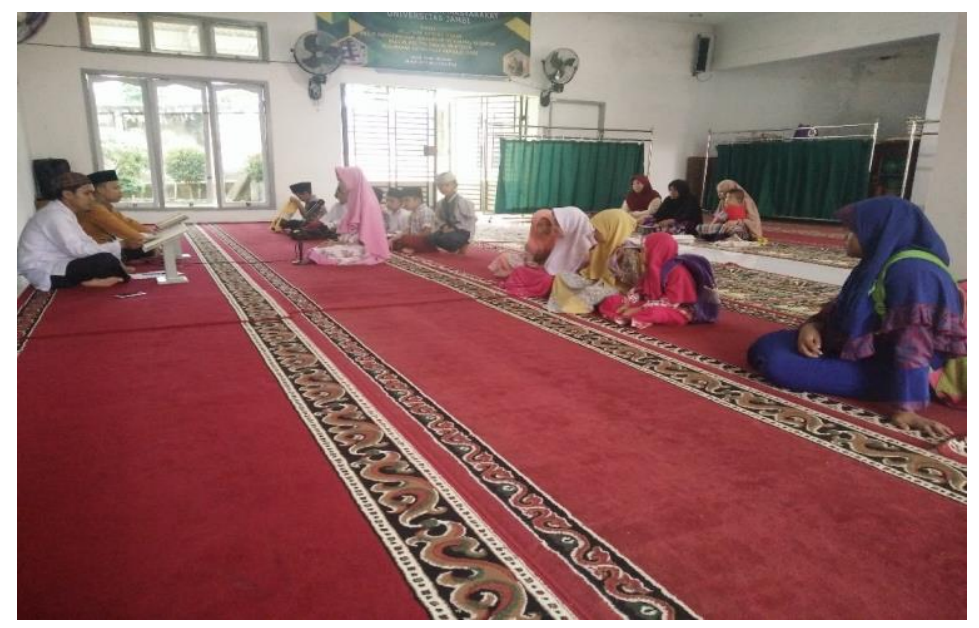

Photo 1:

Keterangan:

Tim pengabdian saat menyampaikan dan menjelaskan materi pengabdian kepada para peserta pengabdian, terlebih dahulu tim mengenalkan apa itu metode Tiqrar, kemudian dilanjutkan dengan mencontohkan penggunaan metode Tiqrar

2. Para peserta menunjukkan reaksi yang positif terhadap belajar penggunaan metode tiqrar, mereka saling berpacu untuk menunjukkan antusias yang tinggi dalam belajar, dan ketika tim pengabdian menyuruh mempraktekkan aplikasi penggunaan metode tiqrar secara bergantian, telihat para peserta pengabdian ini antusias ingin segera mendapatkan giliran. 


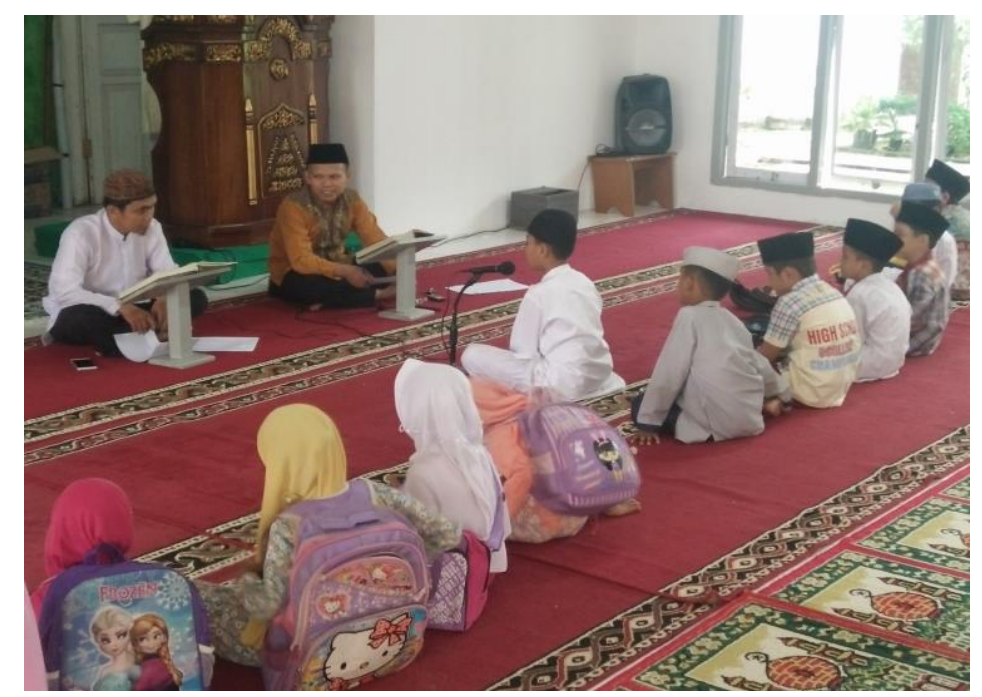

Photo 2:

Keterangan:

Peserta terlihat bersemangat melakukan praktek etode Tiqrar dan terlihat bersabar menunggu giliran tampil dengan tertib.

3. Para peserta aktif bertanya dan mengungkapkan masalah-masalah atau kendala-kendala yang dialaminya selama belajar, dan mereka bersemangat untuk dapat menugasai metode tiqrar dengan baik.

4. Para peserta terlihat bersemangat minta dibimbing secara pribadi ketika tim membuka layanan tersebut, sehingga tim juga merasa senang untuk segera dapat membimbing secara lebih dekat.

5. Para peserta terlihat kompak dan menjalin kerja sama yang cukup baik dalam latihan atau mempraktekkan metode Tiqrar. Mereka tampak saling bantu memperhatikan dalam mempraktekkan metode tiqrar ini.

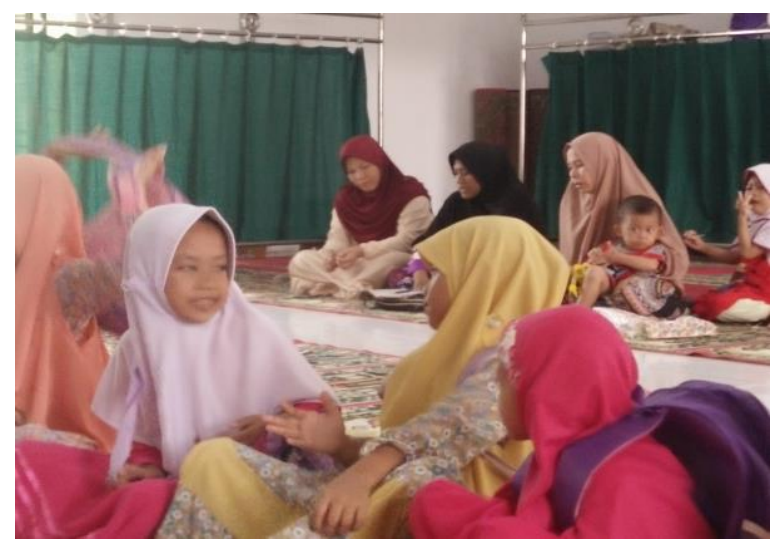

Photo 4:

Keterangan:

Para peserta pengabdian saling berdiskusi dalam kegiatan pengabdian ini. 
6. Ditinjau dari segi materi pengabdian yang disampaikan, banyak pengalaman atau pengetahuan dan keterampilan baru yang diperoleh oleh para murid TPA Sabilal Muhtadin Perumahan Aston Villa Mendalo Darat kecamatan Jaluko kabupaten Muaro Jambi. Yakni mengenai metode Tiqrar yang tim pengabdian kenalkan, yang mana sebagian mereka mengaku baru pertama kali belajar metode Tiqrar, dan ada pula yang pernah belajar namun tidak sampai tuntas.

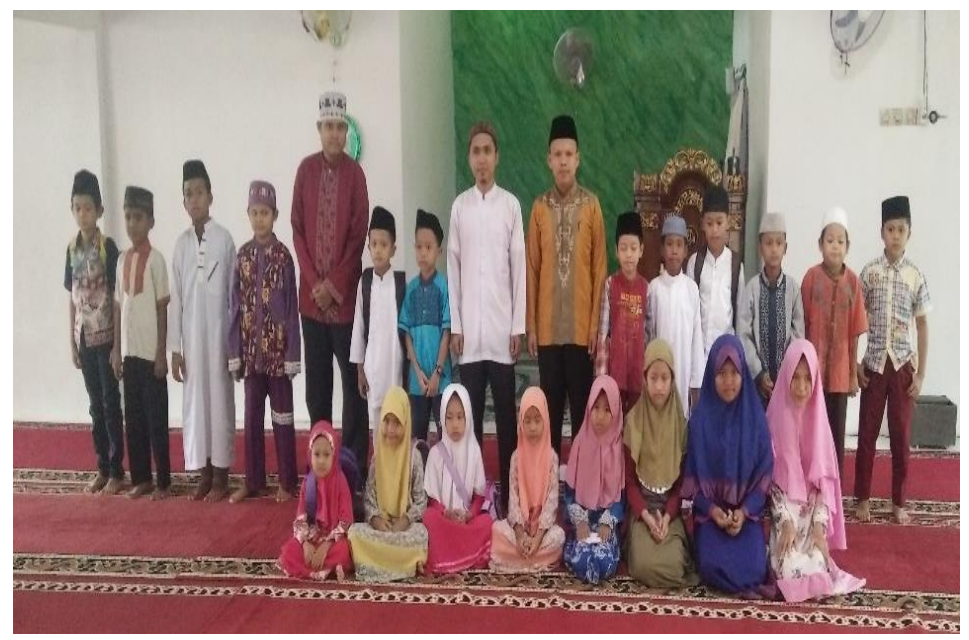

Photo 4:

Keterangan:

Tim pengabdian berphoto bersama para peserta pengabdian setelah pelaksanaan pelatihan penggunaan metode Tiqrar.

Kemudian, bagi tim pengabdian juga memperoleh beberapa input yang bermanfa'at tentang berbagai masalah yang dialami para murid dalam belajar menghafal ayat-ayat suci Al-Qur'an, baik mengenai kendala-kendala yang mereka rasakan dalam mempelajari dan menghafal ayat-ayat suci Al-Qur'an, maupun mengenai rasa senangnya mereka mempelajari dan menghafal ayat-ayat suci Al-Qur'an. Semua pengalaman tersebut dapat tim pengabdian gunakan sebagai bahan pertimbangan untuk melaksanakan pengabdian kepada masyarakat di masa-masa yang akan datang.

Secara umum kegiatan pengabdian kepada masyarakat yang dilaksanakan oleh tim pengabdian masyarakat ini tidaklah menemukan kendala yang cukup serius, dalam artian bahwa pelaksanaan kegiatan ini cukup lancar. Hanya saja karena keterbatasan dana untuk pelaksanaan pengabdian ini, maka menyebabkan keterbatasan bentuk, jenis, dan waktu pelaksanaan kegiatan

\subsection{Pembahasan.}

Setelah menyimak dari pelaksanaan kegiatan pengabdian kepada masyarakat ini dapat dijelaskan bahwa kegiatan ini mendapatkan sambutan yang positif dari masyarakat, khususnya dari para peserta kegiatan pengabdian ini. Yang mana kegiatan serupa sangat jarang dan bahkan belum pernah diadakan sebelumnya di lingkungan murid TPA Masjid Sabilal Muhtadin Aston Villa Mendalo. Dalam pelaksanaannya tim pengabdian selalu dinanti para peserta dengan semangat, mereka berusaha untuk tepat waktu datang ke lokasi kegiatan. 
Ditinjau dari segi materi pengabdian yang disampaikan, banyak pengalaman atau pengetahuan dan keterampilan baru yang diperoleh oleh para murid TPA Sabilal Muhtadin Perumahan Aston Villa Mendalo Darat kecamatan Jaluko kabupaten Muaro Jambi. Yakni mengenai metode Tiqrar yang tim pengabdian kenalkan, yang mana sebagian mereka mengaku baru pertama kali belajar metode Tiqrar, dan ada pula yang pernah belajar namun tidak sampai tuntas.

Kemudian, bagi tim pengabdian juga memperoleh beberapa input yang bermanfa'at tentang berbagai masalah yang dialami para murid dalam belajar menghafal ayat-ayat suci Al-Qur'an, baik mengenai kendala-kendala yang mereka rasakan dalam mempelajari dan menghafal ayat-ayat suci Al-Qur'an, maupun mengenai rasa senangnya mereka mempelajari dan menghafal ayat-ayat suci Al-Qur'an. Semua pengalaman tersebut dapat tim pengabdian gunakan sebagai bahan pertimbangan untuk melaksanakan pengabdian kepada masyarakat di masa-masa yang akan datang.

Secara umum kegiatan pengabdian kepada masyarakat yang dilaksanakan oleh tim pengabdian masyarakat ini tidaklah menemukan kendala yang cukup serius, dalam artian bahwa pelaksanaan kegiatan ini cukup lancar. Hanya saja karena keterbatasan dana untuk pelaksanaan pengabdian ini, maka menyebabkan keterbatasan bentuk, jenis, dan waktu pelaksanaan kegiatan.

Kegiatan ini dinilai sangat bermanfaat bagi anak-anak yang tertarik menghafal ayatayat suci Al-Qur'an. Di tengah-tengah begitu banyak permainan dan aksesoris yang membuat anak-anak lengah dalam belajar, trend menghafal Al-Qur'an di negeri ini kian populer yang membuat hati umat Islam merasa bangga dan bersyukur, kehadiran metode Tiqrar telah lama hadir dan ikut membantu para penghafal untuk mempercepat hafalan mereka. Di mana metode ini mengkondisikan konsentrasi menghafal, sehingga ayat-ayat yang dihafal tidak saja dikuasai dalam waktu yang relatif cepat, tetapi juga hafalan tersebut bertahan dalam ingatan para penggunanya untuk waktu yang lama. Manfaat ini tidak saja dirasakan oleh para penghafal di Indonesia, tetapi juga telah lama dirasakan oleh para penghafal di berbagai negara.

\section{KESIMPULAN DAN SARAN 4.1. Kesimpulan.}

Berdasarkan uraian yang telah dikemukakan pada bagian sebelumnya, diperoleh kesimpulan bahwa kegiatan pengabdian kepada masyarakat ini dapat: 1). Meningkatnya pengetahuan dan kemampuan para murid TPA Sabilal Muhtadin Perumahan Aston Villa dalam menghafal ayat-ayat suci Al-Qur'an dengan menggunakan metode Tiqrar. 2). Meningkatnya semangat para murid TPA Sabilal Muhtadin Perumahan Aston Villa dalam menghafal ayat-ayat suci Al-Qur'an.

\subsection{Saran.}

Berdasarkan kepada hasil yang diperoleh maka dapat disarankan beberapa hal sebagai berikut: 1). Berdasarkan permintaan dari peserta, hendaknya kegiatan-kegiatan seperti ini dapat ditingkatkan frekwensi pelaksanaannya di masa-masa mendatang. 2). Biaya untuk pelaksanaan kegiatan ini hendaknya lebih ditingkatkan, sehingga dapat melaksanakan 
kegiatan lebih variatif dan dalam waktu yang lebih lama.

\section{DAFTAR PUSTAKA}

Ahmad Fatah, (2012). "Dimensi Keberhasilan Pendidikan Islam Program Tahfidz AlQur"an", Skripsi, Jawa Tengah: STAI Pati.

Ahsin Sakho Muhammad, (2017) Oase Al-Qur'an, Jakarta : Qaf.

Muttaqien Said, (2006). Menuju Generasi Qurani, Panduan Menghafal Al-Qur'an, Bekasi: Firma Rodheta.

Sa'dullah, (2008). 9 Cara Cepat Menghafal Al-Qur'an, Jakarta: gema insani, 2008

Khalid ibn Usman as Sabt, (1997). Qawa'id at Tafsir, Jam'an wa Dirasah, Juz. II, tt: Dar ibn

'Affan, 1997

Munawwir. (1984). Kamus Al-Munawwir. Yogyakarta: Pustaka Progresif, 1984

Syaikh Abdul Aziz bin Baz, (2010). Terjemah : Muhammad Iqbal A. Gazali, Keutamaan Menghapal Al-Qur`an, islamhouse.com.

Zulfison dan KH Muharom, (2003). Belajar Mudah Membaca Al-Qur'an dengan metode Mandiri, Jakarta: Ciputat Press. 